\title{
Wojciech Otto \\ Wajda autotematyczny. Wszystko na sprzedaż i Tatarak Andrzeja Wajdy
}

\begin{abstract}
Otto Wojciech, Wajda autotematyczny. "Wszystko na sprzedaż" $i$ "Tatarak" Andrzeja Wajdy [Wajda mise-en-abîme. Andrzej Wajda's "Everything for Sale" and "Sweet Rush"]. „Przestrzenie Teorii" 27. Poznań 2017, Adam Mickiewicz University Press, pp. 151-169. ISSN 1644-6763. DOI 10.14746/pt.2017.27.12.

Mise-en-abîme discourse reveals itself most clearly in 2 films by Andrzej Wajda - Everything for sale and Sweet Rush. These are connected by collective reflexive contexts, as well as by a tendency to promote formal novelty. They can be analysed from the perspective of "a film in a film", which is a story about making a film or "a film about a film", which is a reflection on the cinematographic means of expression.
\end{abstract}

Autotematyzm kojarzony bywa zazwyczaj z terminami: „autorefleksywność”, „refleksywność” i „autoteliczność”. Jego celem jest - jak wskazuje Alicja Helman - przedstawienie stosunku twórcy do tworzywa, środków wyrazu i filmowanych wydarzeń, co ma decydujący wpływ na postawę odbiorcy wobec dzieła ${ }^{1}$. Jako autotematyczne traktuje się te filmy, które charakteryzują się wysokim stopniem samoświadomości medium, ostentacyjnym eksplorowaniem możliwości warsztatu filmowca, traktowaniem kina jako osobistej wypowiedzi w określonym języku (twórczość reżyserów francuskiej Nowej Fali). Z sytuacją bardziej złożoną mamy do czynienia w dziełach, których tematem jest proces twórczy i sama czynność realizacji filmu. Najbardziej znane przykłady to Osiem $i$ pót (1963) Federica Felliniego, Pogarda (1963) Jean-Luca Godarda oraz Noc amerykańska (1973) François Truffauta.

Do tego zaszczytnego grona należy niewątpliwie włączyć również Andrzeja Wajdę. Jego twórczość, rozpoznana dotychczas na wiele sposobów, pozwala interpretować się także w tym kontekście, znamiona autoteliczności zdradzają bowiem i różne jego dzieła. Chociażby Panny $z$ Wilka (1979), gdzie w trzech scenach pojawia się autor pierwowzoru literackiego Jarosław Iwaszkiewicz. Refleksywna w pewnej mierze jest także Kronika wypadków miłosnych (1986), w której z głównym bohaterem, Witkiem, rozmawia pisarz - Tadeusz Konwicki, autor powieści, na pod-

${ }_{1}^{1}$ A. Helman, Autotematyzm, [w:] Stownik filmu, red. R. Syska, Kraków 2010. 
stawie której powstał scenariusz i film. Obaj pisarze, jak stwierdza Matylda Szewczyk, ukazani są jako depozytariusze zaginionego, nieistniejącego już świata: zarówno w wymiarze indywidualnym (dzieciństwo i młodość, które nigdy już nie powrócą), jak i pokoleniowym oraz historycznym - jako świadkowie zagłady świata społecznego spowodowanej przez wybuch wojny i jej następstwa².

Przykładem prawdziwie refleksywnego filmu Wajdy jest również Człowiek z marmuru (1976). Robert Stam nazywa ten utwór „filmem-kompilacją o robieniu filmu-kompilacji”, Tadeusz Lubelski natomiast wskazuje na jego pokrewieństwa ze strukturą Wszystkiego na sprzedaż. Chodzi tu nie tylko o oczywiste pokrewieństwo tematu: i tu, i tam mamy do czynienia z filmem o powstawaniu filmu, ale i o paralelizm kompozycji fabularnej, opartej na rekonstrukcji losu zmarłego bohatera, która służy równocześnie przedstawieniu środowisk współczesnych ${ }^{4}$.

Najbardziej twórczo, wyczerpująco i w czystej formie dyskurs autotematyzmu ujawnia się jednak jedynie w dwóch filmach Andrzeja Wajdy: Wszystko na sprzedaż (1968) i Tatarak (2009). Dzieli je ogromna różnica czasowa - ponad 40 lat, jeśli liczyć daty powstania obu dzieł, ale łączy i zespala wspólnota refleksywnych kontekstów oraz tendencja do promowania formalnego nowatorstwa ${ }^{5}$.

\section{Wszystko na sprzedaż}

Jest to najbardziej wyrazisty, a jednocześnie najbardziej złożony przejaw autotematyzmu w twórczości Andrzeja Wajdy. Film zrodził się nie tylko z pewnej sumy doświadczeń i osobistych przemyśleń reżysera, ale także ze splotów niezwykłych faktów i okoliczności tworzących wyjątkowy ferment intelektualny, który zapanował w ówczesnej sztuce. Tadeusz Szczepański interpretuje ten utwór w pięciu odrębnych planach: mitologicznym, psychologicznym, socjologicznym, moralnym i estetycznym ${ }^{6}$.

2 M. Szewczyk, Lustra $i$ sieci. Przeplatajace sie narracje $i$ warstwy narracyjne we „Wszystko na sprzedaż” $i$ w „Tataraku” Andrzeja Wajdy, „Pleograf. Kwartalnik Akademii Polskiego Filmu" 2016, nr 1.

${ }^{3}$ R. Stam, Reflaxivity in Film and Literature. From Don Quixote to Jean-Luc Godard, New York 1992, s. 1. Podaję za: tamże.

${ }^{4}$ Bardzo obszerna i interesująca analizę owych zależności przeprowadza T. Lubelski, „Mówi do nas”. Wyobrażenie autora w filmach Andrzeja Wajdy, [w:] Filmowy świat Andrzeja Wajdy, red. E. Nurczyńska-Fidelska, P. Sitarski, Kraków 2003, s. 27.

5 Za film Tatarak Andrzej Wajda otrzymał na festiwalu Berlinale nagrodę Alfreda Bauera przyznawaną reżyserom, którzy „wyznaczają nowe perspektywy sztuki filmowej”.

${ }^{6}$ T. Szczepański, Kino autotematyczne (na przykładzie filmu Andrzeja Wajdy „Wszystko na sprzedaż), „Teksty” 1972, nr 3, s. 147. 
W jego ujęciu film Wajdy to przede wszystkim opowieść o fascynującej osobowości aktora, który był inkarnacją pokoleniowego mitu realizującego się w twórczości tego reżysera. Wykorzystując dramaturgię tak zwanych wątków znalezionych, artysta buduje pewien układ fabularny, znajdujący wyraźne oparcie w autentycznej rzeczywistości, i w ten sposób staje na cienkiej krawędzi między sztuką a życiem, a jednocześnie tę krawędź ostentacyjnie pokazuje. Ekranowa iluzja osadza się na dwóch nawzajem sprzężonych formułach: „filmu o filmie” i „filmu w filmie”. Pierwszą stanowi opis własnej sytuacji genetycznej, zawierający refleksje na temat specyfiki kina i roli autora, druga to po prostu relacja o powstawaniu filmu, którego fragmenty pojawiają się na ekranie. Mówiąc krótko, Wszystko na sprzedaż jest filmem o ludziach, którzy robią filmy. Obecność nieobecnego bohatera „filmu o filmie” i „filmu w filmie” pełni funkcję katalizatora wobec postaw bohaterów żyjących, a śmierć owego aktora symbolizuje nie tylko ustąpienie wojennego pokolenia, ale także ustąpienie sztuki, która je wyrażała. W tym sensie utwór Wajdy jest filmem o zmianie pokoleń tak w życiu, jak i w sztuce, i o konieczności tej zmiany.

Nieco odmienną, ale niezwykle interesująca perspektywę przyjmuje Tadeusz Lubelski. Pisze nie o pięciu, ale o trzech warstwach znaczeń utworu i nadaje im wymiar biograficzny oraz historycznofilmowy. Warstwa pierwsza: film o powstawaniu filmu; ginie aktor, który miał grać główną rolę, toteż realizatorzy zastanawiają się nad zmianą pierwotnej konstrukcji, reżyser się waha. Warstwa druga: utwór można traktować jak traktat o możliwościach wyrazowych współczesnego kina. Wreszcie trzecia, najgłębsza warstwa, to historia wewnętrznej przemiany reżysera, który - poprzez doświadczenie samotności - dociera do swego mitu inicjacyjnego, związanego $\mathrm{z}$ sensem sztuki i zobowiązaniem artysty7. W tym znaczeniu film Wajdy jest nie tyle zerwaniem z polską szkołą filmową, ile powrotem do niej, do założeń nurtu, w jakie się uwierzyło w okresie swojej młodości.

Powyższe propozycje interpretacyjne dotykają spraw najistotniejszych, konstytuujących odbiór i zrozumienie filmu Wajdy. Ze względu na złożoną budowę i okoliczności powstania dzieła kuszącym wciąż jednak pozostaje „zanurzenie” się w jego głąb, w żywą tkankę świata przedstawionego i współgrających z nim kontekstów.

Pomysł Wszystkiego na sprzedaż zrodził się na kanwie tragicznych wydarzeń związanych z postacią Zbigniewa Cybulskiego. Aktor zginął w styczniu 1967 roku na wrocławskim dworcu kolejowym, gdy próbował

7 T. Lubelski, dz. cyt., s. 24. 
wskoczyć do jadącego pociągu. Ten wypadek posłużył reżyserowi za punkt wyjścia do opowiedzenia historii o fascynującej osobowości aktora, ale wraz z rozwojem koncepcji filmu i materializowaniem się poszczególnych jego wątków obraz nabierał szerszego wymiaru i stał się bardzo osobistą wypowiedzią autora na kilka kluczowych tematów. Część z nich zawierała się w formule kina stricte autotematycznego, część przybierała natomiast formułę refleksywną, odnoszącą się głównie do polityki autorskiej. Zawiłość konstrukcyjna filmu, luźna fabuła, dekompozycja dramaturgiczna, wielość postaci drugoplanowych - wszystko to spowodowało, że $\mathrm{w}$ filmie, na równych zasadach, zafunkcjonowały rozmaite warstwy/klucze/tropy interpretacyjne. I tak Wszystko na sprzedaż można czytać, po pierwsze, przez pryzmat koncepcji „filmu w filmie”, czyli opowieści o realizacji filmu, w którym główną rolę miał zagrać Zbigniew Cybulski. Można również - po drugie - uruchomić dyskurs „filmu o filmie”, czyli refleksji na temat filmowych środków wyrazu. Równie uprawnionym wydaje się zainicjowanie trzeciego typu interpretacji, czyli koncepcji „filmu o filmowcach", której sens zasadzałby się na przedstawieniu na ekranie rodzimej branży kinematograficznej tamtych lat. Głęboki sens autoteliczny ma w tym przypadku także trop interpretacyjny o roboczej nazwie „film cytat”, pozwalający odnaleźć wszelkie aluzje do wątków i postaci z filmów nakręconych wcześniej. I trop najważniejszy. Wszystko na sprzedaż to bez wątpienia film o artyście - demiurgu, który w progowym momencie swojego życia poszukuje nowej drogi twórczej, a jednocześnie zderza się ze skomplikowaną rzeczywistością i własnymi, wewnętrznymi wątpliwościami. Jak wspomniałem, wszystkie te warstwy/klucze/tropy interpretacyjne zachodzą na siebie, kontaminują się w nowych sensach, problemach i przesłaniach.

Najprościej i w najbardziej czytelny sposób rozgrywa się przed widzem „film o filmowcach”. To oni w końcu są bohaterami tej opowieści i to na nich spoczywa rola zaplatania fabuły. Głównym bohaterem filmu jest aktor, który pewnego dnia nie stawia się na plan zdjęciowy. Wszyscy go szukają, włącznie z jego żoną i reżyserem. Po jakimś czasie dociera wiadomość o jego tragicznej śmierci. Ekipa na czele z reżyserem staje przed trudnym wyborem: zakończyć dopiero co rozpoczęte zdjęcia czy kontynuować pracę $\mathrm{z}$ nowym aktorem, a może stworzyć oryginalną opowieść o aktorze, którego już nie ma? Sytuacja jest niezwykle skomplikowana. Ostatecznie reżyser angażuje w zastępstwie nowego aktora i kontynuuje pracę nad filmem. Tak pokrótce przedstawia się fabuła, ale jest ona zaledwie swego rodzaju szkieletem dla ukazania ważniejszych zjawisk i problemów. Wajda, konstruując scenariusz, zaprojektował w nim przestrzeń dla autentycznych postaci ze świata rzeczywistego. Główni bohaterowie 
noszą takie same imiona lub przezwiska, co odgrywający role aktorzy: Beata (Beata Tyszkiewicz), Elżbieta (Elżbieta Czyżewska), Daniel (Daniel Olbrychski), Witek (Witold Holtz), Kostek (Andrzej Kostenko), Bobek (Bogumił Kobiela), Wiesio (Wiesław Dymny). Wyłom w tym założeniu stanowi jedynie postać reżysera (Andrzeja), w domyśle Andrzeja Wajdy, którego odgrywa zawodowy aktor - Andrzej Łapicki ${ }^{8}$. Pewnym istotnym wyjątkiem w tej regule jest również postać Zbigniewa Cybulskiego, który nie pojawia się na ekranie w żadnym ujęciu (poza rozmazanym portretem na plakacie) i którego imię i nazwisko ani razu nie pada w filmie. Wobec tej postaci Wajda zastosował inny klucz. Cybulski funkcjonuje w filmie w kilku konfiguracjach. W świecie przedstawionym to aktor, którego zaangażował do filmu reżyser (Andrzej), ale na jego wizerunek składają się również elementy wywodzące się $\mathrm{z}$ wykreowanych przez niego wcześniej ról filmowych oraz z autentycznego, prywatnego i zawodowego życia, czyli rzeczywistości pozaekranowej. Wszystkie informacje o nim pochodzą od innych postaci filmowych, począwszy od opisów najbardziej lakonicznych i zewnętrznych, jak relacja „Małej” (Małgorzata Potocka) - domorosłej artystki z kółka recytatorskiego na prowincji, która widziała go zaledwie parę godzin i jedyne, co potrafiła o nim powiedzieć, to to, że dużo mówił, żartował itp.; przez opinie bardziej znaczące i nośne, roznoszone na zasadzie plotek przez środowisko branżowe, opisujące go jako zdeklarowanego patriotę (monolog Bobka cytujący słowo w słowo jego zdanie na temat determinant pochodzenia i miejsca urodzenia), ale też uroczego lekkoducha (opinia Beaty); aż po wyznania najbardziej osobiste, padające z ust jego żony Elżbiety, wyrzucającej mu nieodpowiedzialność i nonszalanckie podejście do życia. Informacje te w pewnym stopniu pokrywają się z rzeczywistością pozaekranową, wymagają jednak dogłębnych analiz i pracy o znamionach detektywistycznych, należy ją zostawić biografom aktora. Wydaje się, że daleko ważniejsze jest prześledzenie pozostałych informacji na jego temat, które pojawiają się w filmie. Są to bardzo interesujące aluzje do filmowych ról Cybulskiego i wykreowanych na ich użytek bohaterów. Najbardziej rozpoznawalną z nich jest postać Maćka Chełmickiego z filmu Popiót $i$ diament (1958) w reżyserii Andrzeja Wajdy, która przyniosła mu uznanie i sławę, stając się ikoną kina tamtych lat. Nawiązaniem do niej jest relacja opiekuna wiejskiej świetlicy opowiadającego o spotkaniu autorskim, podczas którego artysta prezentował, leżąc na podłodze, jak umiera się na ekranie, a także słowa Elżbiety opisującej jego ubiór - dżinsy, plecak przewieszony przez ramię i trampki, pasujący bardziej do postaci Maćka niż samego Cybulskiego. Oba te wizerunki

${ }^{8}$ Andrzej Wajda stwierdził, że nie podołałby tej roli jako aktor. 
kontaminują się i nakładają na siebie, tworząc swego rodzaju bohaterską legendę, zbudowaną przez kino i wzmocnioną przez tragiczną śmierć.

Kreacje postaci drugoplanowych również funkcjonują na styku prawdy i fikcji, na przykład Daniel, Elżbieta i Beata, a także całe środowisko branżowe. Wajda kreuje swoich bohaterów z okruchów informacji dotyczących ich życia prywatnego, wizerunku lansowanego przez ówczesne media oraz ze strzępów ról filmowych, które zagrali. Elżbieta (nazwisko Czyżewska) to bardzo popularna w latach sześćdziesiątych aktorka, tu w roli podwójnej ${ }^{9}$ żony Aktora (Elżbiety Chwalibóg-Cybulskiej), skojarzona $\mathrm{z}$ nią imieniem, oddająca $\mathrm{z}$ dużą dozą wiarygodności problemy małżeńskie Cybulskiego w jego życiu prywatnym. Beata - w czasie realizacji Wszystkiego na sprzedaż prywatnie i w filmie żona Reżysera (Andrzeja Wajdy) z ich wspólnym dzieckiem (Karoliną, pojawiającą się ekranie), jednocześnie żona Aktora i matka ich wspólnego dziecka w realizowanym „filmie w filmie”. Daniel natomiast to kontaminacja trzech powiązanych ze sobą postaci: Daniela Olbrychskiego (utalentowanego młodego polskiego aktora $\mathrm{z}$ lat sześćdziesiątych, uznawanego $\mathrm{z}$ czasem za następcę Cybulskiego w rodzimej kinematografii, głównie za sprawą współpracy z Andrzejem Wajdą), Daniela z filmu głównego, który otrzymuje rolę w zastępstwie zmarłego tragicznie Aktora oraz następca Aktora w realizowanym „filmie w filmie”. Co interesujące, podobnie jak w przypadku Zbigniewa Cybulskiego, postać tę tworzą, oprócz wątków fabularnych ujętych w scenariuszu, także aluzje do jego wcześniejszych ról filmowych, na przykład w rozmowie $\mathrm{z}$ Witkiem padają słowa, że powinien raczej zagrać rolę boksera, co ma odsyłać widza do filmu Juliana Dziedziny Bokser (1966), w którym Daniel Olbrychski zagrał tytułową rolę Tolka Szczepaniaka. Kolejnym bohaterem, odrysowanym tym razem przez Wajdę z dużą dozą krytycyzmu, jest środowisko filmowe - głównie bardziej lub mniej znani aktorzy i aktorki, zepsuci, małostkowi, nadęci, próżni i pretensjonalni. Ich charakter świetnie i w bezpośredni sposób oddaje scena bankietu oraz subtelnie i symbolicznie scena w wesołym miasteczku, gdzie zostają ukarani przez Elżbietę koszmarną jazdą na karuzeli.

W pewnym sensie i w luźnych interpretacjach opowieść o filmowcach współgra z koncepcją filmu traktowanego jako pole do dyskursu autotematycznego wykorzystującego historię kina, a w szczególności jego nośnych i zapadających $\mathrm{w}$ pamięć motywów i postaci, funkcjonujących $\mathrm{w}$ diegezie na zasadzie cytatu filmowego. Pewną jego odmianą są aluzje do ról filmowych służące charakterystyce bohatera, w filmie Wajdy mamy

9 Elżbieta odgrywa żonę Aktora, który zaginął, oraz jego życiową partnerkę realizowanego „filmu w filmie”. 
jednak do czynienia $\mathrm{z}$ bardziej reprezentatywnymi przykładami takich zabiegów. Warto przytoczyć w tym miejscu chociażby scenę rozgrywającą się w warszawskim klubie Kamieniołomy, w której Daniel, ubrany w skórzaną kurtkę Aktora (Zbigniewa Cybulskiego), kupuje butelkę wódki, rozlewa ją do trzech kieliszków, po czym jeden z nich podpala, a pozostałymi dzieli się z Witkiem, asystentem reżysera. $\mathrm{Z}$ boku przygląda się im z zaciekawieniem mężczyzna, w którym łatwo rozpoznać aktora - Adama Pawlikowskiego. To on właśnie zagrał z Cybulskim w pamiętnej scenie z Popiołu $i$ diamentu, z efektownym motywem podpalanych kieliszków wódki, symbolizujących śmierć towarzyszy z AK. Pozostałe cytaty są już odleglejsze i mniej dokładne w stosunku do źródła, raczej o charakterze aluzji lub luźnego skojarzenia. I tak motyw rozkładanego stołu, w którym bohater ukrywał się przed Niemcami podczas okupacji, można odnieść do fabuły filmu Jak być kochana (1962) Wojciecha Jerzego Hasa (paralela z postacią i losami Wiktora Rawicza), biały ręcznik na nadgarstku Elżbiety nasiąkający krwią to wyraźna aluzja do sceny ucieczki Maćka z Popiotu $i$ diamentu, a rekwizyty: chlebak na ramię (plecak) w kolorze zielonym czy metalowy kubek, rzekomo zabrany pierwszemu zabitemu esesmanowi, to przedmioty jakby żywcem wzięte $\mathrm{z}$ filmów wojennych Polskiej Szkoły Filmowej - Popiołu $i$ diamentu w pierwszej kolejności, ze względu na obecność Zbigniewa Cybulskiego, ale może także Kanału (1956) czy Lotnej (1959) Andrzeja Wajdy10.

Użycie filmowych cytatów, czyli pewnego rodzaju gra intertekstualna, to domena kina postmodernistycznego. Ale nie tylko. Pewne jej reprezentacje pojawiały się już w kinie nowofalowym. Wszystko na sprzeda $\dot{z}$, $\mathrm{z}$ racji daty powstania, ale także z powodu eksperymentalnej formy, jest głosem w dyskusji na temat kondycji ówczesnej sztuki filmowej, zwłaszcza w rodzimym wydaniu, i w tym sensie wpisuje się w autotematyczną formułę „filmu o filmie”. Z dotychczasowych rozważań wynika, że pewien model kina, nazwijmy go klasycznym - nastawiony na atrakcyjność fabuły i kult gwiazd, nie ma już racji bytu (w prześmiewczy sposób ukazuje to scena wizyty reżysera na planie zdjęciowym historycznego supergiganta), a środowisko filmowe, podłamane po klęsce marcowej i zatopione we własnych kompleksach, nie jest już w stanie opowiadać o świecie w sposób autentyczny i przekonujący (scena bankietu i scena w wesołym miasteczku). Jak zauważa Tadeusz Lubelski, ten typ kina wymagał całkowitej odnowy, odświeżenia, przemiany, a na horyzoncie ówczesnej kultury

10 Ciekawym tropem, tym razem literackim, może być motyw kręcącej się karuzeli z zamarłymi na niej bohaterami, jako aluzja do chocholego tańca z Wesela Stanisława Wyspiańskiego. 
rysował się jedyny model, podpowiadający realny kształt owej przemiany, model nowofalowy ${ }^{11}$. Film Wajdy wchodzi $\mathrm{z}$ nim w bardzo intensywny dialog. Idąc tokiem rozważań Tadeusza Lubelskiego, zresztą trafnych i konstruktywnych, koniecznym w tym miejscu wydaje się przywołanie tropu przywołującego osobę Jerzego Skolimowskiego. Zamierzeniem Wajdy, niestety niezrealizowanym, było obsadzenie w roli asystenta reżysera właśnie Skolimowskiego ${ }^{12}$, który w tamtym czasie uosabiał w polskim kinie wszystko to, co wiązało się z jego nowofalowym modelem. Ostatecznie role asystentów przypadły Witoldowi Holtzowi i Andrzejowi Kosten$\mathrm{ce}^{13}$. W jednej $\mathrm{z}$ ważniejszych scen filmu ekipa filmowa, po obejrzeniu materiałów kronikarskich z pogrzebu Aktora, staje przed dylematem: co dalej? Swoje propozycje wyjścia z twórczego impasu zgłaszają obaj asystenci. Kostenko nakłania reżysera do wykorzystania modnej wówczas estetyki najzdolniejszego, jak się przez chwilę wtedy wydawało, ucznia nowofalowców, Claude’a Leloucha: „Zrobić to” - podpowiada - „długimi obiektywami, z nieostrym pierwszym planem, bez żadnych pastelowych kolorów, taki jarmark i smutek po facecie, którego już nie ma... Ja w to wierzę". Z kolei Holtz zachęca go do kontynuacji cinéma-vérité: do podsłuchiwania i rejestrowania realnych ludzi. To on chowa się w szafie $\mathrm{z}$ magnetofonem, to on podczas pogrzebu Aktora nagrywa wywiady, niczym francuscy aktorzy Pięknego maja (Ch. Marker) czy Kroniki jednego lata (J. Rouch, E. Morin) ${ }^{14}$. Z pozoru, na pierwszy rzut oka, reżyser - przyzwyczajony do innego sposobu postępowania - odrzuca propozycje każdego z nich. Konstrukcja całości przekonuje jednak, że obie wnoszone przez asystentów propozycje estetyczne zostały zaakceptowane. Zdjęcia zostały przecież nakręcone tak właśnie, jak radził Kostenko. Nie bez powodu całe ujęcia Wszystkiego na sprzedaż określane były mianem „leluchów”. Natomiast wskazówki Holtza (otwierania się na strumień życia) znalazły

11 T. Lubelski, dz. cyt., s. 22.

12 Pomysł Wajdy polegał na tym, aby parę asystentów reżysera zagrali: Jerzy Skolimowski i Andrzej Kostenko - w rzeczywistości dwaj świetnie się dopełniający przyjaciele i współpracownicy, współscenarzyści zrealizowanego na rok przed Wszystkim na sprzedaż prawdziwie europejskiego filmu nowofalowego Start. Niestety, sukces był ledwie połowiczny, gdyż obok Kostenki zamiast Skolimowskiego pojawił się Witold Holtz jako jeden $\mathrm{z}$ asystentów reżysera.

13 Mimo że Jerzy Skolimowski ostatecznie nie pojawił się na ekranie, Wajda przemycił w filmie kilka sygnałów jego obecności, np. stwierdzenie Elżbiety, że zna się na ichtiologii (Elżbieta Czyżewska zagrała wspólnie ze Skolimowskim w jego Rysopisie (1964), w którym główny bohater studiuje właśnie ichtiologię) czy fotografowanie swojej twarzy przez Reżysera (podobny zabieg zastosował Skolimowski w swojej Barierze (1966) - jego twarz pojawia się na plakacie).

14 T. Lubelski, dz. cyt., s. 23. 
swoje spełnienie w scenie finałowej, kiedy to asystent, zafascynowany spontanicznym biegiem za końmi młodego aktora Daniela, radzi reżyserowi porzucić ustalony tok pracy i skierować kamerę na tę manifestację młodzieńczej żywotności. „Przecież to jest wspaniałe!” - woła zachwycony. Reżyser odpowiada na to, $\mathrm{z}$ wyraźnie wyczuwalną nutą sceptycyzmu: „Dobrze, dobrze, rób to dalej sam" - i jest to ostatnia padająca w filmie kwestia ${ }^{15}$.

Przywołanie przez Wajdę poetyki kina nowofalowego uruchamia kolejny dyskurs autotematyczny. Jego sens, wpisujący się w koncepcję „filmu o filmie", polega na wprowadzeniu do problematyki dzieła refleksji o naturze samego medium, o możliwościach i granicach tworzywa filmowego, o powinnościach artysty (demiurga) oraz o aksjologii istnienia zawartej między prawdą, fikcją i kreacją, ale także o jego atrakcyjności i zbieżności z oczekiwaniami odbiorców.

Wyjaśnienie tych kwestii, przynajmniej częściowe, odnaleźć można w podstawowym i konstytutywnym dla filmu Wajdy założeniu konstrukcyjnym, a mianowicie - koncepcji „filmu w filmie”. Jej podstawową konsekwencją jest pewna hierarchiczność kompozycyjna, przybierająca budowę szkatułkową. Pierwszą i najszerszą jej część stanowią konteksty pozaekranowe, odnoszące się do życia prywatnego aktorów występujących w filmie (elementy zewnątrzfilmowe), nieco węższym aspektem są ich wizerunki i motywy zaczerpnięte $\mathrm{z}$ wcześniejszych ról filmowych, które zagrali; idąc dalej w głąb, można wyznaczyć część główną, czyli opowieść o poszukiwaniu aktora, który zaginął i nie stawił się na plan zdjęciowy; na samym końcu natomiast znajdują się fragmenty realizowanego przez ekipę zdjęciową filmu.

Koncepcja „filmu w filmie” rozgrywa się w utworze na dwa sposoby. Pierwszy dostrzec łatwo, ponieważ został zasygnalizowany poprzez użycie taśmy czarno-białej, w zestawieniu z całością filmu, który zrealizowano w kolorze. Taka sytuacja dotyczy dwóch fragmentów: z początku filmu, gdy reżyser próbuje dublować Cybulskiego na planie zdjęciowym, rzucając się pod pociąg; oraz jako kronika z pogrzebu Aktora, którą ekipa filmowa ogląda w studiu. Reżyser, dzięki zastosowaniu prostego zabiegu, informuje widza, że te i tylko te fragmenty stanowią obcą, sztucznie wrzuconą w tkankę filmową, wizualną frazę. Są osobnymi, filmowymi cząstkami. Scena z planu zdjęciowego to jakby fragment filmu, w którym główną rolę miał zagrać Zbigniew Cybulski, jedyny oczywisty i niezaprzeczalny fragment. Kronika $\mathrm{z}$ cmentarza natomiast to także obcy wtręt, materiały $\mathrm{z}$ zainscenizowanego pogrzebu, $\mathrm{z}$ wywiadami i dokumentalny-

15 Tamże, s. 23. 
mi obserwacjami, stwarzające wrażenie telewizyjnego reportażu z medialnego wydarzenia, które - jeśli reżyser przyjmie taką koncepcję - będą dopiero mogły być wykorzystane w jego nowym/starym filmie.

Inne sceny, zaprojektowane przez Wajdę jako kolejne fragmenty przedstawiające realizację filmu w filmie, nie są już takie oczywiste. Najbardziej przekonująco wypada scena finałowa, rozgrywająca się przy torach kolejowych, miejscu rzekomej śmierci Aktora. Świadczy o tym chociażby obecność ekipy filmowej. Na podobnych prawach funkcjonuje scena rozmowy Elżbiety i Beaty w mieszkaniu tej drugiej, ponieważ reżyser wcześniej zapowiada jej realizację w studio, a w finale zdjęć i tym razem zostaje ujawniony kontekst realizacyjny (dyskusje ekipy filmowej, wypłata gaży aktorom). Pojawiają się jednak w filmie i takie fragmenty, które trudno jednoznacznie sklasyfikować. Na pierwszy rzut oka sprawiają wrażenie integralnych części głównego filmu, czyli tego, który opowiada o trudnościach związanych z realizacją filmu Wszystko na sprze$d a \dot{z}$. Pewne zamieszanie i dezinformację wprowadzają jednak krótkie komunikaty podsumowujące owe sceny, na przykład podczas rozmowy Andrzeja z aktorką Teatru Ateneum, w której na końcu reżyser radzi kobiecie: „Co ty robisz z tymi rękami, nie graj tak”, albo w scenie dialogowej Daniela i Witka w klubie Kamieniołomy, którą ten drugi kwituje słowami: „Dobrze to zagrałeś, tak trzeba po śmierci przyjaciela”. Fikcja miesza się z rzeczywistością, prawda z kreacją. Ten komunikacyjny chaos ma $\mathrm{z}$ jednej strony uświadomić widzowi, jak z biegiem czasu zmieniała się koncepcja reżyserska filmu, z drugiej - zrelatywizować wizerunek Zbigniewa Cybulskiego oraz postaci nieobecnego Aktora.

Początkowym zamierzeniem Wajdy była realizacja filmu o tragicznie zmarłym aktorze - Zbigniewie Cybulskim; w trakcie zdjęć, a może już na etapie powstawania scenariusza, artysta zorientował się, że robi film o sobie samym, ale także, niejako przy okazji, o swoich koleżankach i kolegach z branży i o sztuce filmowej - jej statusie, języku i oddziaływaniu na odbiorcę. Pewne wyjaśnienia tych dylematów ujawniają się w poszczególnych frazach dialogowych, podawanych przez aktorów. W scenie w studiu filmowym Bobek tłumaczy reżyserowi: „To będzie film o tobie, jak ty robisz film". W innym miejscu Beata uświadamia mu kolejne kwestie: „Twój film, ale nasze życie”, a aktorka z Teatru Ateneum komentuje z wyrzutem jego postępowanie: „Ważny jest tylko twój aktor, twój film, twój scenariusz. To też jest temat, $\mathrm{z}$ tego też można zrobić film”. Reżyser sam nie pozostaje bez wątpliwości. W rozmowie $\mathrm{z}$ Witkiem pyta zatroskany: „A nie myślisz, że jesteśmy jak hieny?”, „Czy ciebie to nie dręczy, jaki on był naprawdę?”, a w innym miejscu dodaje: „Jakie filmy mogę robić, z kim, o czym?”, „Myślałem, że będzie z tego coś prawdziwego na

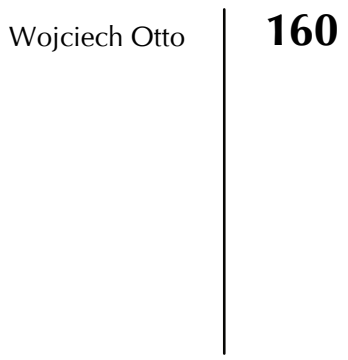


ekranie". Postać reżysera jako bohater filmowy, ale też alter ego samego Andrzeja Wajdy, stanowi figurę, wokół której rozgrywają się najważniejsze wątki fabularne, ale też skupiają się w niej najistotniejsze dylematy twórcze autora. Andrzej (Andrzej Wajda) jest z jednej strony członkiem środowiska branżowego, które nomen omen sam poddaje zjadliwej krytyce, $\mathrm{z}$ drugiej - w pewnym sensie od tego środowiska ostentacyjnie się odcina (scena bankietu, w której reżyser trzyma się z dala od całego towarzystwa). Jego postawa i charakter wynikają z odgórnie założonego przez Wajdę planu co do tej postaci. Andrzej to poszukujący swojej drogi twórczej artysta, znajduje się właśnie w przełomowym momencie życia i przeżywa wewnętrzny kryzys. Ma świadomość, że w sztuce, także filmowej, wiele się zmieniło w ciągu ostatniej dekady, pojawiły się nowe nurty i kierunki, nowe estetyki i nowa, wymagająca publiczność. Chcąc wyjść temu naprzeciw, musi wyznaczyć dla siebie i dla uprawianej przez siebie sztuki nową perspektywę. Jako doświadczony i ceniony reżyser unika wszelkich mód i naśladownictw, intensywnie poszukując drogi dla modelu kina, pod którym mógłby, bez najmniejszej dozy konformizmu, sam się podpisać. $\mathrm{W}$ ostatecznym rozrachunku rezygnuje nawet $\mathrm{z}$ atrakcyjnego modelu kina nowofalowego (w ostatniej scenie „oddaje” film asystentom) i pozostaje wierny samemu sobie, powracając do mitów Polskiej Szkoły Filmowej i patronujacym im, przynajmniej w jego mniemaniu, autorytetom. Tadeusz Lubelski wskazuje na dwa $\mathrm{z}$ nich: Zbigniewa Cybulskiego i Andrzeja Wróblewskiego. Obaj umocnili go niegdyś w przeświadczeniu, które zdobył we wczesnej młodości: że sztuka jest misją, i podpowiedzieli sens tej misji. Cybulski, który niedawno zginął, narzucił się jako temat i problem. Wróblewski zmarł wprawdzie dziesięć lat wcześniej, ale „odżył" na nowo w jego głowie dzięki zorganizowanej wówczas jubileuszowej wystawie jego prac w Poznaniu i Warszawie ${ }^{16}$. Obaj w przeszłości patronowali jego drodze twórczej: Cybulski jako ikona Szkoły Polskiej, Wróblewski poprzez płótna ze słynnego cyklu „Rozstrzelań” (lata 1948-1949), nawiązującego do dramatu II wojny światowej. Pod koniec filmu Andrzej, szukając kolejnych inspiracji, udaje się na wystawę prac Wróblewskiego, ogląda z uwagą jego przygnębiające dzieła, następnie wspólnie z Beatą jadą samochodem ulicami Warszawy. Zza szyb auta, na drugim planie, rozpościera się panorama miasta, która za sprawą zachodzącego właśnie słońca wygląda jakby spowijały je płomienie. W przebitkach tych obrazów pojawiają się flashowe ujęcia przedstawiające płótna Wróblewskiego, a wcześniej, przez dłuższą chwilę, widnieje na ekranie wiele mówiący napis wyryty na pobliskim postumencie: „Tu dn. 11.XII. 1943 r. hitlerow-

16 Tamże, s. 25. 
cy rozstrzelali 40 Polaków". Wojna, a z nią samotność i śmierć, jako wiodące tematy Polskiej Szkoły Filmowej, wracają w tym momencie ze zdwojoną siłą i stają się dla bohatera, ale także samego Wajdy, wciąż żywą tradycją i niezatartym punktem odniesienia, tak w kwestii tematu, jak i sprawdzonej estetyki, do których zawsze można się odwołać, poszukując nowych, twórczych horyzontów i snując refleksje na temat współczesnej sztuki.

\section{Tatarak $^{17}$}

Andrzej Wajda przymierzał się do adaptacji opowiadania Iwaszkiewicza przez wiele lat, napotykał jednak na trudności adaptacyjne. Tatarak to miniatura literacka, która jako filmowa fabuła zamyka się w formule krótkiego metrażu. Na film kinowy to za mało. Należało więc poszukać albo innego opowiadania Iwaszkiewicza, które by korespondowało z Tatarakiem, albo rozbudować istniejący tekst o historię współczesną. Pierwszą możliwość z góry wyeliminowano, gdyż - jak wyraził się reżyser - utwór Iwaszkiewicza stanowi sam w sobie arcydzieło małej formy, wewnętrznie spójne, zamknięte i skończone ${ }^{18}$. Spróbowano zatem drugiej ewentualności. Scenariusz wzbogaciła o wątki współczesne znana pisarka Olga Tokarczuk. Napisała historię niespełnionego romansu poza planem zdjęciowym aktorki odtwarzającej główną rolę. Efekt okazał się satysfakcjonujący. Gdy zdjęcia dobiegały już końca, Janda niespodziewanie pokazała Wajdzie kilkanaście stron tekstu jej autorstwa o przebiegu choroby i niedawnej śmierci Edwarda Kłosińskiego - jej męża, cenionego operatora filmowego. Po lekturze reżyser zrozumiał, że dopiero teraz zaczyna się dla niego właściwa praca nad tym filmem. Znalazł bowiem punkt odniesienia dla tekstu literackiego Iwaszkiewicza. Tak powstała ostateczna wersja scenariusza. Oś fabularną stanowiła historia krótkiego romansu starszej, śmiertelnie chorej kobiety - Marty z młodym, dwudziestoletnim mężczyzną, który w momencie rozkwitu wzajemnej fascynacji ginie tragicznie na jej oczach. Historię tę Wajda rozbudował o krótkie opowiadanie pt. Nagte wezwanie z tomu Magia autorstwa Sándora Máraiego. Wyraźnie oddzieloną fabularnie opowieść tworzy monolog Krystyny Jandy, który kompozycyjnie przeplata się z losami granej przez nią bohaterki. Zachowując formę teatralnego monodramu, aktorka zdradza

17 Rozważania na temat filmu „Tatarak” zawierają tezy i częściowe analizy z mojego tekstu opublikowanego w periodyku „Images” 2009, nr 13-14.

18 Iść za losem filmu. Z Andrzejem Wajdą rozmawia Tadeusz Lubelski, „Kino” 2009, nr 4, s. 9 . 
w nim kulisy śmierci jej męża, opowiadając przy tym o najbardziej intymnych szczegółach swojego życia osobistego. Jest jeszcze trzeci fabularny wymiar tego utworu, nawiązujący w pewien sposób do drugiego. To zastosowanie formuły tak zwanego filmu w filmie, czyli kompozycyjnej ramy ukazującej poszczególne etapy realizacji filmowego Tataraku. $\mathrm{Z}$ pozoru tylko dwa pierwsze elementy fabuły wydają się spójne i logicznie zespolone; zawierają wspólny temat - śmierć, i dzięki temu, mimo ogromnych różnic narracyjnych i czasoprzestrzennych, stanowią swego rodzaju problemową wspólnotę, tematyczny monolit. Element trzeci stricte autotematyczny - sprawia wrażenie oderwanego od całości. Istnieje w tkance filmowej jak obcy twór, który razi sztucznością i nieprzystawalnością stylistyczną, rozbijając obraz świata przedstawionego i burząc przejrzystą i przemyślaną analogię elementów wcześniejszych, zbudowaną raz na zasadzie podobieństw (temat), kiedy indziej znowu w konfrontacji (przestrzeń). Jego obecność należy tłumaczyć nieco inaczej, bardziej jako próbę uniwersalizacji autorskiego przesłania lub twórczą autokreację, niż spójny fabularnie element diegezy filmowej. Jest też, podobnie jak Wszystko na sprzedaż, swego rodzaju opowieścią o artyście, tyle że już doświadczonym i spełnionym reżyserze filmowym, który z jednej strony dokonuje osobistej rekonstrukcji i podsumowania swojego twórczego dorobku, z drugiej - kolejnym filmem udowadnia, że nie zamierza w żadnym razie kończyć swojej przygody z kinem.

Rozwarstwienie konstrukcyjne filmu nie ma wyraźnego, kategorycznego charakteru. Poszczególne warstwy istnieją w dziele filmowym nie na zasadzie odrębnych, nieprzenikalnych wątków czy opowieści, lecz bardzo często ulegają kontaminacji, zachodzą na siebie, uzupełniają się i wzajemnie się komentują.

Materiał literacki, czyli opowiadanie Iwaszkiewicza i literacka miniatura Máraiego, stanowią podstawową płaszczyznę fabularną dzieła. Z filmowego Tataraku wyłania się obraz polskiej rzeczywistości drugiej połowy lat pięćdziesiątych, uchwycony przez Iwaszkiewicza i twórczo zaadaptowany z wykorzystaniem tekstu Máraiego przez Andrzeja Wajdę. Następne warstwy skupiają się już na czymś innym. Wychodzą poza rzeczywistość literacką w stronę niezwykle osobistych, autentycznych historii oraz artystycznej autokreacji i filmowego autotematyzmu. Reżyser wzbogacił film o wątki współczesne. Pierwszy z nich to opowieść Krystyny Jandy, będąca osobistą relacją z przebiegu choroby i śmierci jej męża, przy czym należy wyraźnie zaznaczyć, że aktorka występuje tu w trojakiej roli: jako autorka Zapisków ostatnich, czyli krótkiego tekstu literackiego, który wspólnie $\mathrm{z}$ reżyserem zaadaptowała na potrzeby filmu; jako artystka sceniczna odgrywająca jedną z aktorskich ról i, wreszcie, 
jako autentyczna postać ze świata pozaekranowego. Drugi wątek współczesny stanowi dla filmu autotematyczną ramę, ukazując kulisy realizacji filmowego Tataraku. Chodzi w tym przypadku przede wszystkim o opowiadanie przez artystę historii o sobie samym, nie tylko w kontekście wspólnego filmu, lecz także w ujęciu szerszym - całego twórczego dorobku i związanej z tym pozycji społecznej. Zarówno Wajda, jak i Janda kreują na ekranie swój artystyczny wizerunek. Odkrywają też przed widzem swoje ludzkie oblicze. Realizują wspólnie ważny dla obojga film, ale niejako przy okazji zdradzają również, jak wiele łączyło ich w przeszłości i kim sa dla siebie dzisiaj ${ }^{19}$.

Film rozpoczyna znamienne zdanie, padające $\mathrm{z}$ ust aktorki w jej pierwszym monologu: Ten film mieliśmy robić $w$ zeszłym roku. Otrzymujemy więc jako widzowie pewną autorską, metatekstową wskazówkę, sugerującą rozwarstwienie i szersze odczytanie utworu. I zabieg ten zostaje konsekwentnie przeprowadzony w kolejnych scenach. Osobista opowieść Jandy, wyrażona $\mathrm{w}$ trzech obszernych monologach, zawiera z jednej strony intymne szczegóły jej życia prywatnego, z drugiej zaś jest swego rodzaju relacją ukazującą początki powstawania filmowego Tataraku na etapie inspiracji, pomysłu i pierwszych prób realizacyjnych. Ciąg dalszy, czyli poszczególne dni zdjęciowe, pojawiają się w filmie już nie $\mathrm{w}$ formie słownej relacji, ale wprost - jako fragment reportażu z planu zdjęciowego. Obserwujemy najpierw pierwsze próby czytane z udziałem reżysera i aktorów odtwarzających główne role - Krystyny Jandy (Marta) i Jana Englerta (lekarz, mąż Marty), a następnie przygotowania ekipy filmowej do realizacji pierwszej, właściwej, tzn. odnoszącej się fabularnie do opowiadania Iwaszkiewicza, sceny filmu. Ostatecznie pojawia się klapser i inicjuje rozpoczęcie zdjęć. Rzeczywistość filmowa kontaminuje się zatem ze światem utworu literackiego, na razie poprzez czytane przez aktorów fragmenty tekstu, ale tekstu niezwykle ważnego, układającego się bowiem w swoiste motto, przesłanie dzieła, mówiące o przemijalności ludzkiego losu, nagłości i nieprzewidywalności śmierci oraz konfrontacji młodości i witalności ze smutną i ponurą starością.

W ciekawy sposób skonfrontowano także pierwowzór literacki z wizją przyszłego filmu. Reżyser w dużej mierze dochował wierności opowiadaniu Iwaszkiewicza. Pozostawił w niezmienionym kształcie literackie dialogi, ogólny zarys postaci, tak zewnętrzny, jak i wewnętrzny, oraz przebieg zdarzeń, rozbijając tok opowiadania jedynie osobistymi wypowiedziami Jandy i ujęciami z planu zdjęciowego. Umiejętnie wkompono-

${ }^{19}$ Krystyna Janda wystąpiła w kilku filmach Andrzeja Wajdy, między innymi w Człowieku z marmuru, Dyrygencie, Człowieku z żelaza; oboje też uważają się za przyjaciół. 
wał również w fabułę miniaturę literacką Máraiego, dzięki której rozbudował postać męża Marty i wzbogacił obraz ich wzajemnych relacji. Stary doktor nie jest, jak u Iwaszkiewicza, tylko zapracowanym, beznamiętnie dorabiającym się majątku lekarzem. W filmie postać ta nabiera zdecydowanie więcej pozytywnych cech. To człowiek szalenie wrażliwy i choć powściągliwy w okazywaniu uczuć, bardzo kochający swoją żonę. Wizja jej nieuchronnej śmierci podłamuje go i zmusza do głębokiej refleksji. To właśnie z jego ust, podczas rozmowy z żoną, pada znamienne zdanie: „Życie tak łatwo może stać się śmiercią". Taki wizerunek bohatera implikuje rzecz jeszcze bardziej istotną. Wyraźna opozycja między starzejącym się i oschłym uczuciowo lekarzem a pełnym witalności i młodzieńczego piękna Bogusiem, zawarta w pierwowzorze literackim, tutaj zostaje nieco zatarta, dzięki czemu romans pani Marty nie wynika jedynie z frustracji zaniedbywanej żony. Jej relacja $\mathrm{z}$ mężem to jakby odwrócony wariant prywatnej historii opowiadanej przez aktorkę, to także symboliczny obraz nieustannie ścierających się w życiu opozycji: młodości i starości, nadziei i jej braku, piękna i brzydoty.

Dzięki drobnym korektom większej siły wyrazu nabrał ponadto drugi plan, głównie wizerunek starej znajomej z Warszawy, granej przez Jadwigę Jankowską-Cieślak. Koleżanka odwiedza panią Martę rutynowo, jak to miała w zwyczaju czynić co jakiś czas. Tym razem jednak jej wizyta nie wynika, jak poprzednio, jedynie z kurtuazji i grzeczności, co sugeruje w swoim utworze Iwaszkiewicz, ale ma ona do spełnienia swego rodzaju misję. Na prośbę doktora, męża Marty, przywozi wyniki jej badań, które okazują się bardzo niepomyślne, zwiastując poważną chorobę i rychłą śmierć. Znajoma ze stolicy inicjuje poza tym jeszcze jeden wątek - wspomnienie tragicznych zdarzeń z okresu powstania warszawskiego, w którym zginęli dwaj synowie Marty. Wątek ten został przez Wajdę świadomie uwypuklony i rozszerzony. Bohaterka wciąż żyje z tą rodzinną traumą i nie może się z nią pogodzić. Jak sama mówi - jest jej „wstyd wobec wszystkich zmarłych”, jeszcze bardziej, kiedy widzi ,jakieś młode życie, bo młodość jest bezwstydna". Można dodać, że młodość nie dopuszcza myśli o śmierci, choć ta - jak poucza historia - dotyczy wszystkich bez wyjątku. W symboliczny sposób ukazuje to $\mathrm{w}$ filmie scena będąca jakby mglistym wspomnieniem z dzieciństwa. W pokoju dwaj chłopcy bawią się piłką, nagle obaj wybiegają za nią do ogrodu, po jakimś czasie do pokoju wraca już tylko sama piłka. Ta krótka scena została ukazana na ekranie $\mathrm{w}$ zwolnionym tempie, $\mathrm{w}$ nienaturalnie rozświetlonym lub zacienionym obrazie, co nadało jej wymiar pewnej odrealnionej, symbolicznej wizji, fragmentu snu bądź strzępów odległych wspomnień. 
Przenikanie obu światów odbywa się także nieco subtelniej, w ujęciach łączących elementy $\mathrm{z}$ różnych rzeczywistości, na przykład obraz mężczyzny siedzącego na schodkach przed kamienicą, którego podczas spaceru na przystań mija Marta ze swoją starą znajomą. Mężczyzna nie przystaje do realiów Polski końca lat pięćdziesiątych, ponieważ ubrany jest w dżinsową katanę, której popularność przypadła w kraju na kilka dekad później. Podobnie scena ukazująca zabawę na przystani, zakończona długim szwenkiem przedstawiającym barwną okolicę $\mathrm{z}$ zabytkowym zamkiem i starymi murami obronnymi w tle, przed którymi członkowie ekipy filmowej zaparkowali swoje samochody. Nie bez znaczenia jest też wygląd zewnętrzny głównej bohaterki. Warto zauważyć, że łączy ona w sobie elementy aż trzech filmowych opowieści. Wyraźnie oddzielona pozostaje postać Krystyny Jandy jako aktorki przygotowującej się do gry w filmie Wajdy (próby czytane na planie filmowego Tataraku, aktorka ubrana w sportową kurtkę i przeciwsłoneczne okulary), zdecydowanie więcej wspólnych cech posiada w sobie literacko-filmowa Marta i Krystyna Janda wygłaszająca swój osobisty monolog. Mimo iż wiemy, że jest to jej prywatna, autentyczna historia, sposób zachowania przed kamerą, profesjonalizm gry i swoisty dystans, jaki aktorka wytworzyła na planie, daje złudzenie, że obcujemy na ekranie z fikcyjną postacią, której przydarzyła się w życiu rodzinna tragedia. Tym, co łączy obie bohaterki w niektórych scenach, jest strój - te same czarne buty na wysokim obcasie i czarna garderoba; tym, co dzieli - kolor oczu i włosów. Mamy tu też odwrócenie sytuacji życiowej - Marta jest śmiertelnie chora, a Janda opowiada o śmierci w kontekście historii jej męża, obie zaś stykają się z procesem umierania, nagłym bądź rozłożonym w czasie.

Wspomniane trzy opowieści filmowe spotykają się w osobie Marty-Aktorki-Jandy w jednej scenie, kiedy podczas zrywania tataraku tonie Boguś, a bohaterka próbuje go ratować. Nagle tok opowiadania zostaje przerwany. Krystyna Janda wynurza się z wody i, powodowana jakimś pierwotnym instynktem, szybko i ku zaskoczeniu całej ekipy filmowej opuszcza plan zdjęciowy. Przemoczona, ubrana jedynie w strój kąpielowy, w strugach deszczu łapie na pobliskim moście tak zwaną okazję i odjeżdża w niewiadomym kierunku. Gdy na tylnym siedzeniu przykrywa się płaszczem właściciela pojazdu, z offu zaczyna rozbrzmiewać ostatni monolog bohaterki, wygłaszany do tej pory jedynie w pustym, hotelowym pokoju. Padają znamienne słowa: „Od 12 czerwca wiedzieliśmy, że jest chory. Był po drugiej chemii, znosił to nieźle. Dał mi do zrozumienia, że nie chce, abym robiła film, chce, żebym z nim była. [...] Nie potrafię myśleć o Tataraku osobno od niego, śmierć krąży nad tym tekstem”. Potem następuje przebitka na plan zdjęciowy, gdzie ekipa zbiera sprzęt, ucieka- 
jąc przed ulewą. Kolejna scena to znowu monolog aktorki, tym razem jak w poprzednich odsłonach - w ciemnym pokoju hotelowym. Janda opisuje ostatnie chwile życia swojego męża i sam moment śmierci. I dopiero po tych wszystkich retardacjach kamera powraca w toń jeziora, ukazując tonącego Bogusia i próbującą uwolnić się z jego więzów Martę. Jeszcze tym razem udaje jej się umknać przed śmiercią. Sprowadza ratunek, który okazuje się spóźniony i daremny. Boguś umiera.

W jednej krótkiej sekwencji pojawiają się więc sceny z rozmaitych warstw filmowej opowieści. Jest tu zarówno niespełniony romans Marty i Bogusia z noweli Iwaszkiewicza, jeden z monologów Jandy, jak i cząstkowy, autotematyczny, reportaż z planu zdjęciowego. Elementy te następują zaraz po sobie, stwarzając na ekranie wrażenie spójnego opowiadania $\mathrm{z}$ nadrzędnym, organizującym całość motywem śmierci. Bardzo efektownie prezentuje się ucieczka aktorki $\mathrm{z}$ planu $\mathrm{w}$ najważniejszym momencie filmu - w chwilę przed śmiercią Bogusia. W tym miejscu zostaje wprowadzony wątek $z$ osobistej opowieści Jandy i siłą rzeczy burzy dramaturgię utworu. Ale tylko na chwilę. Monolog bowiem odpowiada tematycznie sytuacji, w której znaleźli się bohaterowie noweli; ma też wewnętrzną dramaturgię, wywołaną poprzez kulminację emocji i wrażeń. Najsłabiej prezentuje się na ekranie trzecia warstwa filmowej opowieści. Zaskoczenie, które wywołuje u członków ekipy realizatorskiej niekontrolowana, zdawało by się, ucieczka aktorki, brzmi z gruntu fałszywie. Nasuwa się bowiem pytanie: skąd kamera towarzysząca Jandzie w jej spontanicznej eskapadzie? Gdyby pominąć ten fakt, należy docenić wysiłek reżysera, który umiejętnie scalił rozwarstwienie konstrukcyjne dzieła i nadał opowiadanej historii uniwersalny wydźwięk.

Wątek autotematyczny w Tataraku pojawia się już w jego pierwowzorze literackim, czyli w noweli Iwaszkiewicza. Od samego początku autor aranżuje w utworze sytuację opowiadania, stylizowaną na relację $\mathrm{z}$ rzeczywistości, $\mathrm{z}$ osobą pisarza $\mathrm{w}$ centrum ${ }^{20}$. To jemu zapach tataraku przypominał „zawsze śmierć pierwszego przyjaciela, który nosił dziwaczne imię Gracjan i utopił się, mając trzynaście lat”; to on - dojrzały, bo sześćdziesięcioczteroletni literat, odwiedzał „doktorową M.” „w małym miasteczku Z. położonym nad wielką rzeką", kiedy wykryto u kobiety „objawy chronicznej a nieuleczalnej choroby”, i to on właśnie spisał jej historię ,jak literat, uzupełniając i dodając" to, co podsuwała mu wyobraźnia. Zapach śmierci, który stał się wspólnym doświadczeniem starszego pisarza i bohaterki jego opowiadania, implikował szersze odczyta-

${ }^{20}$ Zwraca na to uwagę Tadeusz Lubelski, Tatarak (recenzja filmu), „Kino” 2009, nr 4, s. $58-60$. 
nie utworu. U jego podstaw znajdowała się sugestia, aby obnażyć przed odbiorcą samego siebie, siebie jako artystę i człowieka, z bagażem przeszłości i refleksją o stanie obecnym. W przypadku Wajdy i jego filmu proste przeniesienie tego literackiego chwytu z oczywistych względów wypadłoby sztucznie i mało przekonująco. Kim innym jest bowiem autor dzieła i inna rzeczywistość, w której film powstawał. Reżyser zdecydował więc, że zaaranżuje odrębną, filmową opowieść, która posłuży mu za miejsce osobistej kreacji. Ramą tej opowieści są oczywiście pierwsze próby czytane Iwaszkiewiczowskiego Tataraku z udziałem samego reżysera, Krystyny Jandy i Jana Englerta. Pozostałe elementy tego dyskursu rozsiane zostały dyskretnie po całym świecie przedstawionym filmu. Najciekawszy kontekst uruchamiają dwa motywy: piosenka Pamiętasz, była jesień, rozbrzmiewająca z ekranu podczas owej próby czytanej z Jandą, oraz książka Jerzego Andrzejewskiego Popiót $i$ diament, którą pani Marta chce pożyczyć Bogusiowi do poczytania. Oba utwory - muzyczny i literacki - można z powodzeniem odnieść do polskich filmów z okresu Szkoły Polskiej. Są to: Pożegnania Wojciecha Jerzego Hasa i Popiót i diament Andrzeja Wajdy. Oba miały swoją premierę niemal w tym samym czasie ${ }^{21}$, oba też należą do kanonu rodzimej kinematografii. Co najważniejsze, dzięki przywołaniu tych tytułów reżyser uruchomił wyraźny kontekst autobiograficzny, zwracając tym samym uwagę widza, że sam staje się bohaterem swojego filmu. Tatarak można bowiem interpretować jako dzieło rozrachunkowe, dzieło uznanego i doświadczonego twórcy, który w wieku osiemdziesięciu dwóch lat przegląda się w swoich filmach jak w lustrze, a tym samym przygląda się sobie jako artyście i człowiekowi. Mierzy się z poważnym tematem - śmiercią, a siebie umieszcza $\mathrm{w}$ jego centrum.

Inaczej wizerunek artysty kreuje w filmie Krystyna Janda. W trzecim monologu, po przejmującym opisie ostatnich chwil życia jej męża, pyta jakby retorycznie: „Jak ja mogłam zagrać tego wieczoru?” (czyli w dniu śmierci męża). Można zadać jeszcze jedno pytanie, które wprost w filmie nie pada: „Jak ja mogłam zagrać w Tataraku Wajdy?” (w takim Tataraku). Chodzi tu o rozstrzygnięcie kwestii powinności aktora jako artysty i granic etycznych z tym związanych. Aktorka z jednej strony odkrywa swoje czysto ludzkie oblicze - jest przecież takim samym człowiekiem, jak osoby zasiadające $\mathrm{w}$ teatrze $\mathrm{w}$ rzędach przeznaczonych dla publiczności - jak one przeżywa radość i cierpienie, z drugiej zaś ukazuje siebie jako artystkę, która odczuwa imperatyw spełniania się na scenie i która jednocześnie - poprzez swoją grę - zaspokaja potrzeby i oczeki-

${ }^{21}$ Pożegnania 13 października, a Popiót i diament 3 października 1958 roku.

Wojciech Otto


wania odbiorcy. Wystawienie na forum swojego prywatnego życia i to w tak ekshibicjonistycznej formie, staje się dla aktorki swego rodzaju psychologiczną autoterapią. To jednak także element wypowiedzi artystycznej, pełen autentyzmu i profesjonalizmu wykonania. I jeśli nie przekracza granicy dobrego smaku ani nie wyrządza krzywd moralnych, zasługuje na miano sztuki.

Dwa dzieła literackie, osobista opowieść, wątek autotematyczny wszystko to składa się na autorską koncepcję współczesnego kina. To oryginalna wizja dojrzałego reżysera, który w kinie od wielu lat, z pewnością także od czasu powstania Wszystkiego na sprzedaz, poszukuje nowych inspiracji - tematycznych, plastycznych czy literackich, który wciąż potrafi zadziwiać międzynarodową publiczność.

Tatarak Andrzeja Wajdy to historia ze śmiercia w tle, film o przemijaniu, wiecznej opozycji młodości i starości, o człowieku zadającym pytania o sens życia. Dzięki zastosowaniu hybrydycznej formy filmowej reżyser poszerzył pole społecznych i kulturowych kontekstów, można nawet powiedzieć, że w pewnym stopniu osłabił siłę oddziaływania Iwaszkiewiczowskiego pierwowzoru na rzecz wątków współczesnych. Powstało dzieło nowatorskie, w którym zapach śmierci - kluczowe doznanie autora i jego bohaterów - stał się centralnym motywem ogniskującym w sobie sumę filmowych znaczeń i spajającym konstrukcyjne rozwarstwienie utworu.

\section{BIBLIOGRAFIA}

Helman A., Autotematyzm, [w:] Stownik filmu, red. R. Syska, Kraków 2010.

Iść za losem filmu. Z Andrzejem Wajdą rozmawia Tadeusz Lubelski, „Kino” 2009, $\mathrm{nr} 4$.

Lubelski T., „Mówi do nas”. Wyobrażenie autora w filmach Andrzeja Wajdy, [w:] Filmowy świat Andrzeja Wajdy, red. E. Nurczyńska-Fidelska, P. Sitarski, Kraków 2003.

Lubelski T., Tatarak (recenzja filmu), „Kino” 2009, nr 4.

Szczepański T., Kino autotematyczne (na przykładzie filmu Andrzeja Wajdy „Wszystko na sprzedaż), „Teksty” 1972, nr 3.

Szewczyk M., Lustra $i$ sieci. Przeplatajace się narracje $i$ warstwy narracyjne we „Wszystko na sprzedaz” $i w$ „Tataraku” Andrzeja Wajdy, „Pleograf. Kwartalnik Akademii Polskiego Filmu” 2016, nr 1. 
